\title{
Study on Factors Affecting Equipment Management and its Effect on Productivity in Building Construction
}

\author{
R. Ranjithapriya ${ }^{[1]}$ \\ ${ }^{[1] P . G . ~ S t u d e n t, ~}$ \\ Department of Civil Engineering, \\ Coimbatore Institute of Technology, \\ Coimbatore, India
}

\author{
Dr. S. Arulselvan ${ }^{[2]}$ \\ ${ }^{[2]}$ Associate prof., \\ Department of Civil Engineering, \\ Coimbatore Institute of Technology, \\ Coimbatore, India
}

\begin{abstract}
Construction equipment is one of the important resources of modern day construction in the building sites. Equipment selection is an important factors in the implementation of many construction projects. Equipment managers are habitually called upon to make economical decisions involving the machines in their charge. Their duties includes repairs, rebuilds, and maintenance. Around 30-40\% of construction cost overrun is caused by inappropriate supervision of equipments. The purpose of this paper is to identify the various factors affecting equipment management which effects the productivity in construction sites. The main goal of the research study is to provide essential information about factors affecting equipment management to the project management teams who enable the project's success. The questionnaire was categorized into the profile of respondents and the factors in three different groups. This profile were created to collect the information such as job position, experience and contact information. Factors affecting equipment productivity were ranked on the basis of relative importance index method. Based on analysis, the factors which affect equipment productivity are late inspection, condition of sites, operators efficiency and availability of skilled operators.
\end{abstract}

\section{INTRODUCTION:}

Equipment is one of the key factors for civilizing contractors ability in performing their work more successfully and efficiently. Monitoring the productivity of manpower and equipment project by using spearman's ranking and correlation coefficient of factor analysis (*Mudumbai Krishnaswamy Parthasarathy1 and Kavitha Murugesan2, 2017). In most cases, equipment maintenance strategy of effective construction were recognized and contributed extremely to the project cost overrun by frequency analysis method (1,Tsado, Theophilus Yisa , 2,Theophilus Yisa Tsado, 2014). Classification of the criteria and its effect on equipment selection, is measured. Developing a framework for the selection of equipment management. Uses of new equipment and modern methods had been possible in the research_(1Janki Patel, 2Dr.Neeraj Sharma, 3Rushabh Shah, 2017). Here the model uses arithmetic and geometric gradient method for the future life cycle costs of the equipment which yields the minimum present value of total costs is required _(A. Collier, 1 David E. Jacques2 , 2015). Selecting the equipment that consider the job condition and gives the lower costs. Identifying the equipment optimization of profit analysis and also the equipment production analysis is a combination of lowest operating cost and highest production (A. N. Bhirud1, V. D. Sakhare2, 2015). Examine the factors that affecting productivity of well-organized utilization of hauling equipment in earth moving operations using fuzzy set theory. Fuzzy set evaluation framework is used for the assessment and prioritization of factors should be considered_(A. Salem, A. Salah, M. Ibrahim, and O. Moselhi, 2017). Breakdown and efficiency improvement are conceded out by define, measure, analyze, improve, control (DMAIC) method. To assess productivity by improving the equipment efficiency (Amir Azizi, 2015). To improve the productivity of equipment management in multi storey building construction projects based on the logistic regression models for the probability of baseline productivity. This research study about designed and proper extension for the construction equipment management for enhanced productivity. Evaluating overall traffic flow of construction equipment which influences the efficiency of the project (D. B. Phadatare S. B. Charhate, 2016). Analysis were used in modeling obsolescence costs in the equipment alternate analysis and study about the alteration in equipment productivity adjusting the cost inflations and making some specific suggestions considering the numerical formulas_(Ittiphol Bhurisith1 and Ali Touran, , 2002). Recognition of the factors effect on equipment assortment and proper use of suitable equipment will give economy, quality, time completion, operation and maintenance and also gives clarification for the logical assessment of overall factors \#jariwala. Identifying the number of factors of simulation productivity analysis model for the construction workforce. The different models were taken to select the equipment for productivity and remedial measures can be applied in the building sites (Prakash H. Panda\#1, Mr. Sahajanand Kamat\#2, 2017). This paper analyses the time series modeling methods that gives both point and period terms to predict the failures and other consistency characteristics for the predictive performance for construction equipment. Tracking the situation of equipment to recognize the failures (Qing Fan and Hongqin Fan, 2015). Estimating the methods of life cycle costs and decision methods were compared. The various elements to be measured though purchasing the equipment and optimizing the effectiveness_(Saikumar Tenepalli SS. Asadi K. Sai Kala, 2017). Factors affecting 
productivity of equipment resources for the top organization of the project. Implementing organization tools for improving and increasing the output (Venkatesh M.P1 and Saravana Natarajan P.S2, 2019).

\section{EQUIPMENT MANAGEMENT:}

The selection of construction equipment for a work site is a key factor to be measured for time completion of the project within the predetermined budget. The cost efficiency is a main criteria of construction equipment management. Another major characteristics of effective construction equipment management is a defensive maintenance which can helps to save a lot of time, cost and reduce delays in project. Equipment is an item that is portable from small hand tools through truck, crane. The complexity of today's construction projects are makes it harder to appraise equipment alternatives and makes the right selection of equipment. Based on their experience, equipment managers decide on day-to-day management of equipment operations, and also on tactical operations such as new equipment procurement. Thus responsibilities of the equipment managers, ensuring that the equipment is properly used, maintained, utilized, and managed, are rather challenging. Effective operation of construction equipment should be maintained to avoid under exploitation of such huge investment. Also repair and maintenance should be carefully intended and high productivity rates should be realized during operations.

Research methodology:

The research has been investigated in order to identifying the factors that mostly affecting equipment management in construction. A questionnaire was targeting about the factors affecting equipment management in the various types. This division contains classification of causes, collections and suggestions. Distributing the questionnaires to the employees involved in the implementation of the selected organization. Each respondents had a choice to select only one option for each set of questions. The responses were to be based on the understanding, significant and experience.

\section{DATA COLLECTION AND ANALYSIS:}

One of the most important segment is a data collection. Data collection is the procedure of collecting essential data report for a certain sample. A plan was formulated for collecting field survey and creating an assessment process and statistical values. It was essential to make available a respondents to ensure a clear understanding of all the appropriate definitions, measures, and guidelines were used in data collection. Here, Relative importance index method is used in the data. This method was used to ranking the overall factors and to decide various professional's opinions in the construction projects. RII is calculated as given below

$\mathrm{RII}=\sum \mathrm{W} /(\mathrm{A} * \mathrm{~N})$

Where,

$\mathrm{W}$ is the weight given by the each factor

W ranges 1 . Very low 2. Low 3. Moderate 4. High 5. Very high $\mathrm{A}$ is the highest weight 5

$\mathrm{N}$ is the total number of responses.

\section{MANAGEMENT FACTORS AFFECTING EQUIPMENT MANAGEMENT:}

Table 1 and figure 1 shows that the ranking of various management factors . Late inspection was ranked first in the management factors with an RII value of 0.681

Table 1. Factors under management factors

\begin{tabular}{|c|c|c|c|}
\hline S.No. & Factors & RII & Rank \\
\hline 1 & $\begin{array}{l}\text { Will the Late inspection of equipment affect the } \\
\text { productivity of equipment's? }\end{array}$ & 0.681 & 1 \\
\hline 2 & $\begin{array}{l}\text { Do the type of soil at sites affect equipment } \\
\text { productivity? }\end{array}$ & 0.678 & 2 \\
\hline 3 & $\begin{array}{l}\text { Do the condition of sites have any role in equipment } \\
\text { productivity? }\end{array}$ & 0.675 & 3 \\
\hline 4 & $\begin{array}{l}\text { Will Giving training to the operators of equipment } \\
\text { helps in increasing equipment productivity? }\end{array}$ & 0.647 & 4 \\
\hline 5 & Budgeting & 0.614 & 5 \\
\hline 6 & $\begin{array}{l}\text { Did routine checking affect overall productivity of } \\
\text { equipment? }\end{array}$ & 0.611 & 6 \\
\hline 7 & $\begin{array}{l}\text { Will the work Scheduling of equipment affect } \\
\text { equipment productivity? }\end{array}$ & 0.611 & 6 \\
\hline 8 & $\begin{array}{l}\text { How much influence is there for the Improper cash } \\
\text { flow that effect equipment maintenance? }\end{array}$ & 0.583 & 8 \\
\hline
\end{tabular}




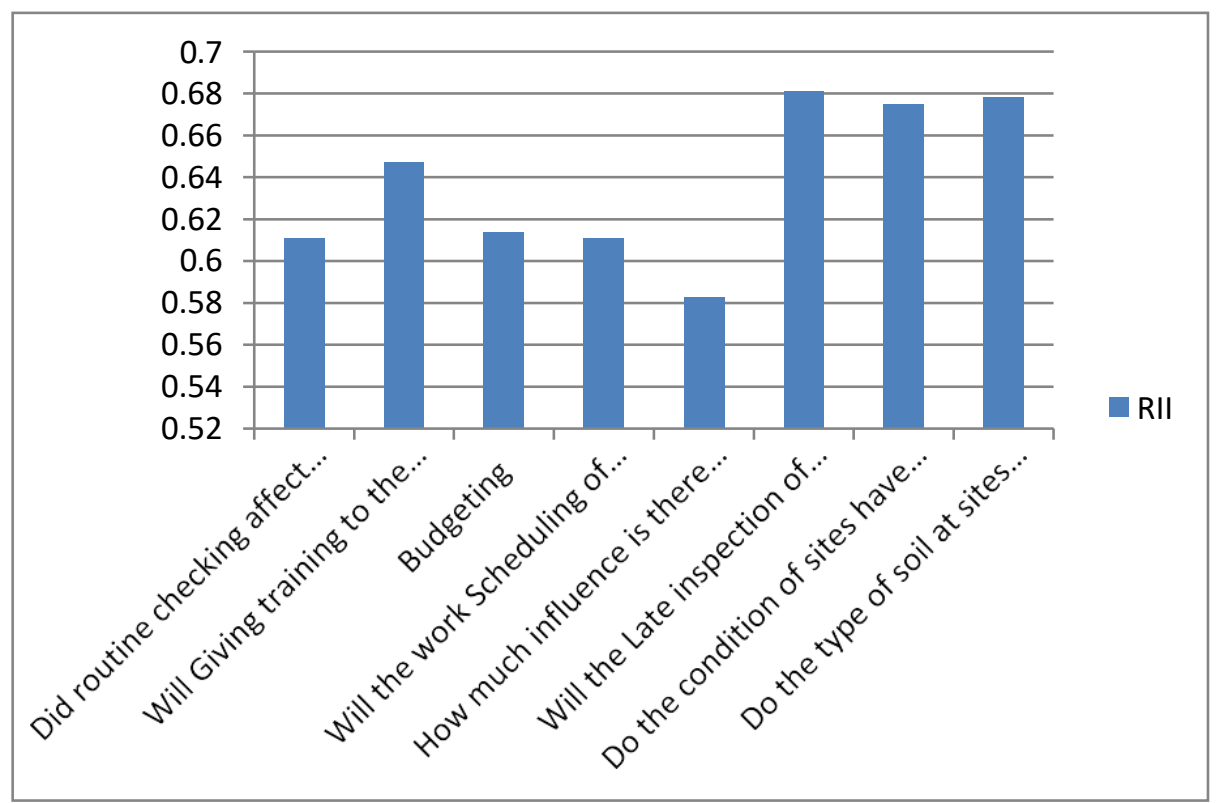

Figure 1. Management factors

\section{FACTORS AFFECTING WORKFORCE CHARACTERISTICS:}

Under workforce characteristics factor operators efficiency was ranked with an RII value of 0.675 , each equipment has a unique performing character.

Table 2. Factors affecting workforce characteristics

\begin{tabular}{|c|l|c|c|}
\hline S.No. & \multicolumn{1}{|c|}{ Factors } & RII & Rank \\
\hline 1 & $\begin{array}{l}\text { Will the Operators efficiency in handling equipment } \\
\text { affect equipment productivity? }\end{array}$ & 0.675 & 1 \\
\hline 2 & $\begin{array}{l}\text { Will the Availability of skilled operators for particular } \\
\text { equipment's affect productivity? }\end{array}$ & 0.658 & 2 \\
\hline 3 & $\begin{array}{l}\text { Does Poor training of equipment's to operators affect } \\
\text { equipment productivity? }\end{array}$ & 0.642 & 3 \\
\hline 4 & $\begin{array}{l}\text { Do the past experience of worker with equipment affect } \\
\text { its overall productivity? }\end{array}$ & 0.633 & 4 \\
\hline 5 & $\begin{array}{l}\text { Do the Financial problems in project } \\
\text { have any role in equipment productivity? }\end{array}$ & 0.622 & 5 \\
\hline 6 & $\begin{array}{l}\text { Does the Frequent change of labors who works on } \\
\text { equipment affect productivity? }\end{array}$ & 0.594 & 6 \\
\hline 7 & $\begin{array}{l}\text { Will the lack of financial motivation to the workers } \\
\text { affect productivity? }\end{array}$ & 0.592 & 7 \\
\hline 8 & $\begin{array}{l}\text { Will the morality of workers affect equipment } \\
\text { productivity? }\end{array}$ & 0.556 & 8 \\
\hline
\end{tabular}




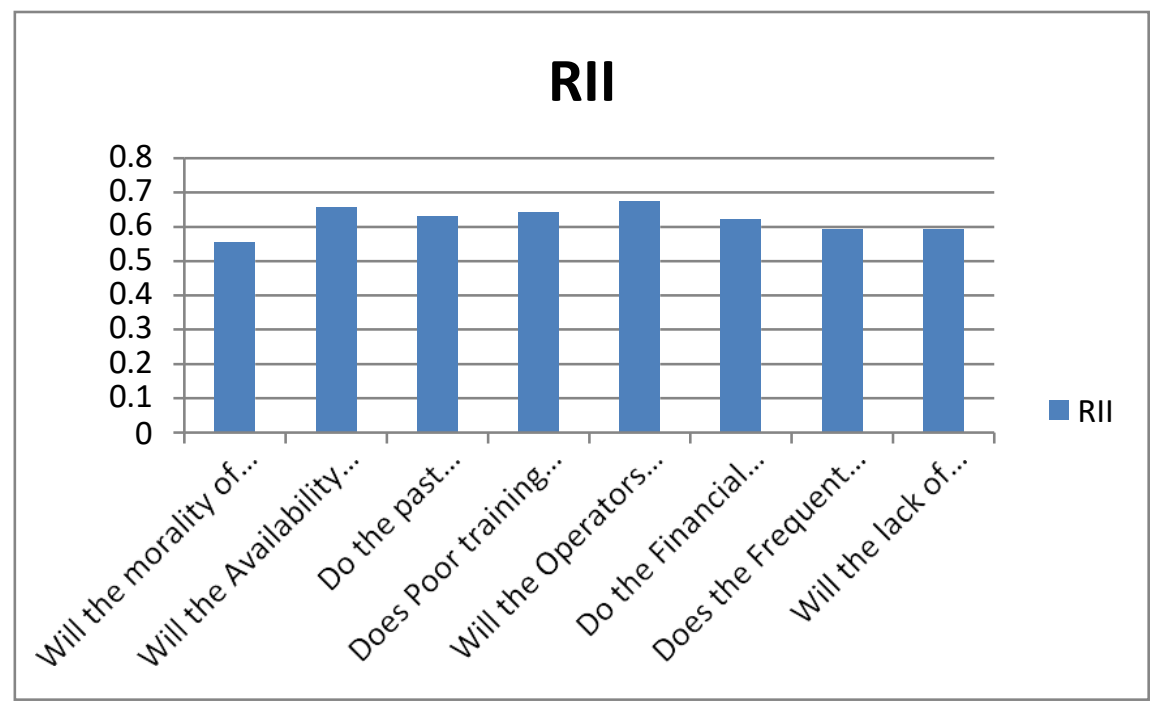

Figure 2. workforce characteristics

FACTORS AFFECTING EQUIPMENT CHARACTERISTICS:

Availability of servicing part of equipment has ranked first among the equipment characteristics. So care should be taken while choosing an equipment of spare parts availability and its repairing.

Table 3. Factors affecting equipment characteristics

\begin{tabular}{|c|l|c|c|}
\hline S.No. & \multicolumn{1}{|c|}{ Factors } & RII & Rank \\
\hline 1 & $\begin{array}{l}\text { Will the easily availability of Servicing parts of equipment affect } \\
\text { productivity? }\end{array}$ & 0.661 & 1 \\
\hline 2 & Do the possibility of easy repair of spares affect its productivity? & 0.653 & 2 \\
\hline 3 & Does the Equipment efficiency affect productivity? & 0.647 & 3 \\
\hline 4 & Will the operating life of equipment affect productivity? & 0.642 & 4 \\
\hline 5 & Do Availability of spare parts affect productivity? & 0.642 & 4 \\
\hline 6 & Does the Capacity of equipment affect productivity? & 0.636 & 6 \\
\hline 7 & Does the Speed of equipment affect productivity? & 0.633 & 7 \\
\hline 8 & Does the Age of equipment affect productivity? & 0.633 & 7 \\
\hline & $\begin{array}{l}\text { Do Predicting time of failure of equipment before and servicing them } \\
\text { helps in improving productivity? }\end{array}$ & 0.625 & 9 \\
\hline 10 & $\begin{array}{l}\text { Do the frequent Changing old lubricants at regular time intervals } \\
\text { affect productivity? }\end{array}$ & 0.619 & 10 \\
\hline 11 & $\begin{array}{l}\text { Will Replacing pats known to experience age and related degradation } \\
\text { have any role in equipment's productivity? }\end{array}$ & 0.617 & 11 \\
\hline 12 & Will Lack of new technology affect productivity? & 0.617 & 11 \\
\hline 13 & Does High cost of spares have any role in equipment's productivity? & 0.611 & 13 \\
\hline 14 & Do the Size of equipment have any role in equipment management? & 0.553 & 14 \\
\hline
\end{tabular}




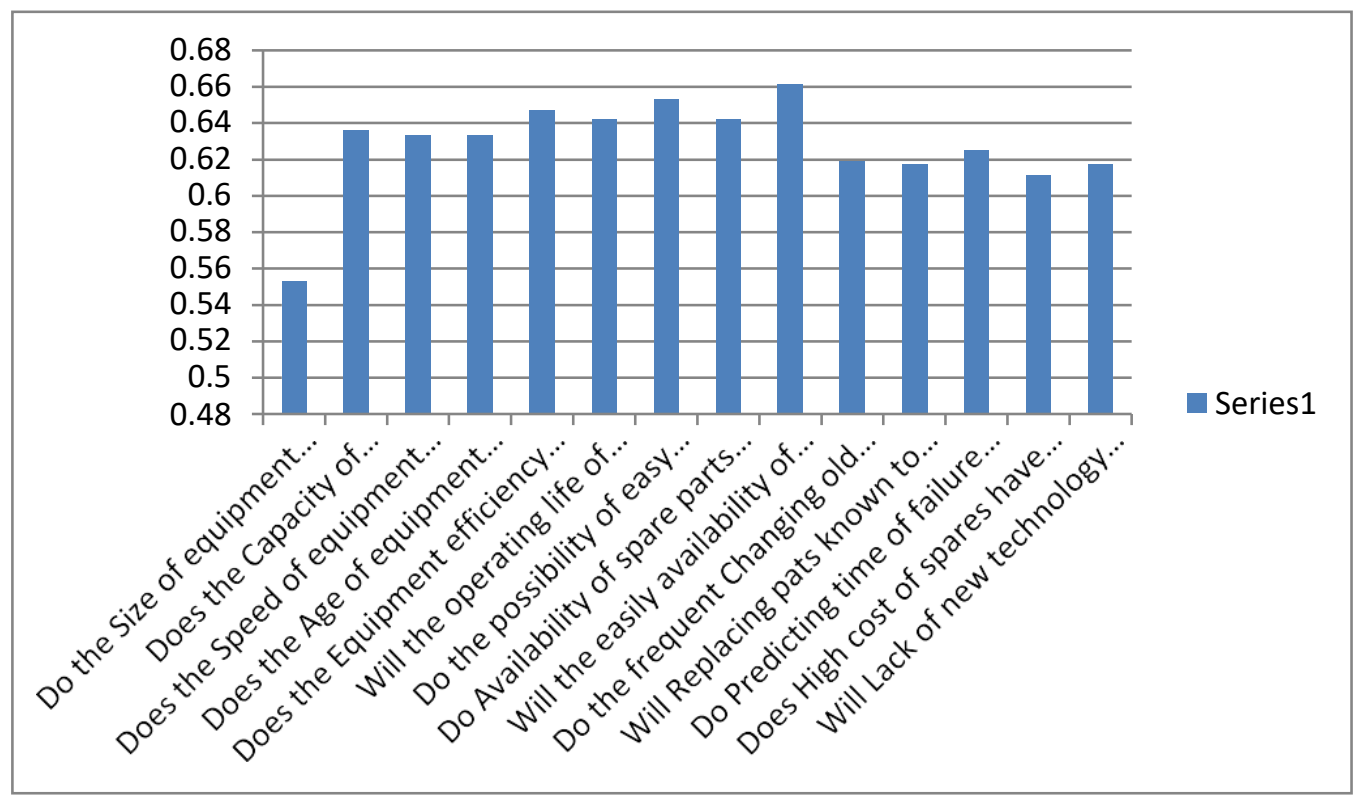

Figure 3. Equipment characteristics

OVERALL FACTORS AFFECTING EQUIPMENT MANAGEMENT:

The following table and graph shows the overall ranking of factors affecting equipment management in a building construction.

Table 4. Overall factors affecting equipment management

\begin{tabular}{|c|c|c|c|}
\hline S.No & Factors & RII & Rank \\
\hline 1 & $\begin{array}{l}\text { Will the Late inspection of equipment affect the } \\
\text { productivity of equipment's? }\end{array}$ & 0.681 & 1 \\
\hline 2 & $\begin{array}{l}\text { Do the type of soil at sites affect equipment } \\
\text { productivity? }\end{array}$ & 0.678 & 2 \\
\hline 3 & $\begin{array}{l}\text { Do the condition of sites have any role in } \\
\text { equipment productivity? }\end{array}$ & 0.675 & 3 \\
\hline 4 & $\begin{array}{l}\text { Will the Operators efficiency in handling } \\
\text { equipment affect equipment productivity? }\end{array}$ & 0.675 & 3 \\
\hline 5 & $\begin{array}{l}\text { Will the easily availability of Servicing parts of } \\
\text { equipment } \\
\text { affect productivity? }\end{array}$ & 0.661 & 5 \\
\hline 6 & $\begin{array}{l}\text { Will the Availability of skilled operators for } \\
\text { particular equipment's affect } \\
\text { productivity? }\end{array}$ & 0.658 & 6 \\
\hline 7 & $\begin{array}{l}\text { Do the possibility of easy repair of spares affect its } \\
\text { productivity? }\end{array}$ & 0.653 & 7 \\
\hline 8 & $\begin{array}{l}\text { Will Giving training to the operators of equipment } \\
\text { helps in increasing equipment productivity? }\end{array}$ & 0.647 & 8 \\
\hline 9 & $\begin{array}{l}\text { Does the Equipment efficiency affect } \\
\text { productivity? }\end{array}$ & 0.647 & 8 \\
\hline 10 & $\begin{array}{l}\text { Does Poor training of } \\
\text { equipment's to operators affect equipment } \\
\text { productivity? }\end{array}$ & 0.642 & 10 \\
\hline 11 & $\begin{array}{l}\text { Will the operating life of equipment affect } \\
\text { productivity? }\end{array}$ & 0.642 & 10 \\
\hline 12 & Do Availability of spare parts affect productivity? & 0.642 & 10 \\
\hline 13 & $\begin{array}{l}\text { Does the Capacity of } \\
\text { equipment affect productivity? }\end{array}$ & 0.636 & 13 \\
\hline 14 & Do the past experience of & 0.633 & 14 \\
\hline
\end{tabular}




\begin{tabular}{|c|c|c|c|}
\hline & $\begin{array}{l}\text { worker with equipment affect } \\
\text { its overall productivity? }\end{array}$ & & \\
\hline 15 & $\begin{array}{l}\text { Does the Speed of equipment } \\
\text { affect productivity? }\end{array}$ & 0.633 & 14 \\
\hline 16 & $\begin{array}{l}\text { Does the Age of equipment } \\
\text { affect productivity? }\end{array}$ & 0.633 & 14 \\
\hline 17 & $\begin{array}{l}\text { Do Predicting time of failure of equipment before } \\
\text { and servicing them helps in improving } \\
\text { productivity? }\end{array}$ & 0.625 & 17 \\
\hline 18 & $\begin{array}{l}\text { Do the Financial problems in project have any role } \\
\text { in } \\
\text { equipment productivity? }\end{array}$ & 0.622 & 18 \\
\hline 19 & $\begin{array}{l}\text { Do the frequent Changing old lubricants at regular } \\
\text { time } \\
\text { intervals affect productivity? }\end{array}$ & 0.619 & 19 \\
\hline 20 & $\begin{array}{l}\text { Will Replacing pats known to experience age and } \\
\text { related degradation have any role in } \\
\text { equipment's productivity? }\end{array}$ & 0.617 & 20 \\
\hline 21 & $\begin{array}{l}\text { Will Lack of new technology } \\
\text { affect productivity? }\end{array}$ & 0.617 & 20 \\
\hline 22 & Budgeting & 0.614 & 22 \\
\hline 23 & $\begin{array}{l}\text { Did routine checking affect } \\
\text { overall productivity of equipment? }\end{array}$ & 0.611 & 23 \\
\hline 24 & $\begin{array}{l}\text { Will the work Scheduling of equipment affect } \\
\text { equipment } \\
\text { productivity? }\end{array}$ & 0.611 & 23 \\
\hline 25 & $\begin{array}{l}\text { Does High cost of spares have any role in } \\
\text { equipment's } \\
\text { productivity? }\end{array}$ & 0.611 & 23 \\
\hline 26 & $\begin{array}{l}\text { Does the Frequent change of } \\
\text { labors who works on equipment affect } \\
\text { productivity? }\end{array}$ & 0.594 & 26 \\
\hline 27 & $\begin{array}{l}\text { Will the lack of financial } \\
\text { motivation to the workers affect productivity? }\end{array}$ & 0.592 & 27 \\
\hline 28 & $\begin{array}{l}\text { How much influence is there for the Improper } \\
\text { cash flow that effect equipment maintenance } \\
\text { ? }\end{array}$ & 0.583 & 28 \\
\hline 29 & $\begin{array}{l}\text { Will the morality of workers } \\
\text { affect equipment productivity? }\end{array}$ & 0.556 & 29 \\
\hline 30 & $\begin{array}{l}\text { Do the Size of equipment have } \\
\text { any role in equipment management? }\end{array}$ & 0.553 & 30 \\
\hline
\end{tabular}




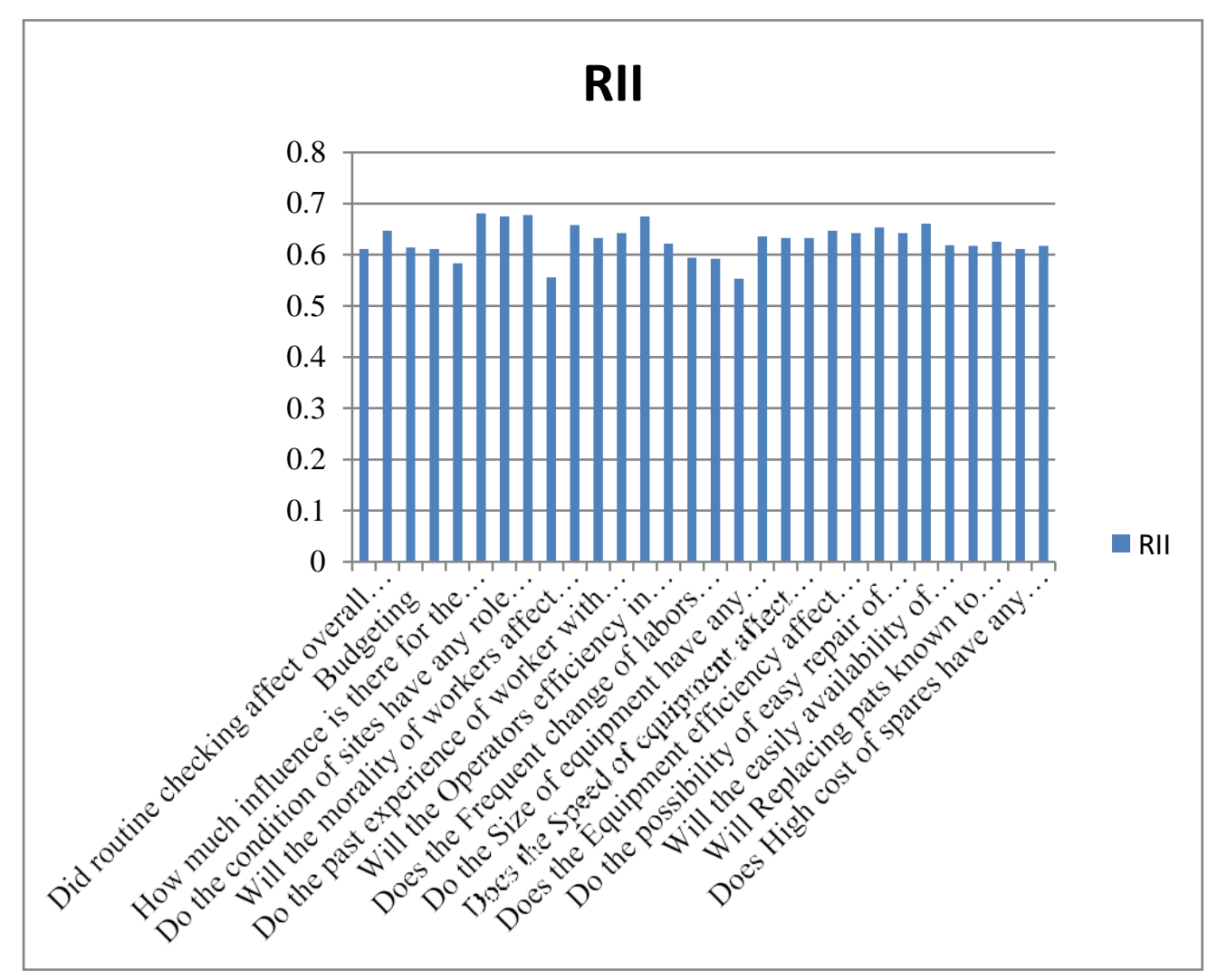

Figure 4. Overall factors affecting equipment management

\section{CONCLUSIONS:}

Factors affecting equipment management are many in the construction firms. Prior knowledge of equipment management during construction can save money and time. Investments for these projects are very high because of the difficulty in construction, various factors can affect exceedingly in productivity. This research is proposed to recognize the causes of feasible factors under equipment management in construction. This study investigates all the feasible factors throughout a questionnaire. The survey results are subjected to ranking of factors is considered by using RII method. The range of RII for workforce factors is between $0.556-0.675$. The range of management factors is between 0.583-0.681. The range of equipment characteristics is between 0.553-0.661. Based on the analysis it find out the workforce factors, late inspection, soil condition, operators efficiency, availability of spare parts are the foremost factors affecting equipment management in the construction.

\section{REFERENCES:}

[1] *Mudumbai Krishnaswamy Parthasarathy1 and Kavitha Murugesan2. (2017). A Critical Review of Factors Affecting Manpower and Equipment Productivity in Tall Building Construction Projects. Journal of Construction in Developing Countries , 1-18.

[2] 1,Tsado, Theophilus Yisa , 2,Theophilus Yisa Tsado. (2014). Equipment Maintenance: An Effective Aspect Of Enhancing Construction Project Profitability. International Journal of Engineering Science Invention, 34-41.

[3] 1Janki Patel, 2Dr.Neeraj Sharma, 3Rushabh Shah. (2017). A
Critical Literature Review on Criteria for Effective Selection Of Equipment And its Management in Construction Industry. International Journal of Advance Engineering and Research Development, 156-161.

[4] A. Collier,1 David E. Jacques2 . (2015). OPTIMUM EQUIPMENT LIFE BY MINIMUM LIFE- CYCLE COSTS. J. Constr. Eng. Manage. , 248-265.

[5] N. Bhirud1, V. D. Sakhare2. (2015). Construction Equipment Monitoring and its Effect on Project Cost. International Journal of Science and Research, 1447-1450.

[6] Salem, A. Salah, M. Ibrahim, and O. Moselhi. (2017). Study of Factors Influencing Productivity of Hauling Equipment in Earthmoving Projects using Fuzzy Set Theory. International Journal of Innovation, Management and Technology, 151-154.

[7] Amir Azizi. (2015). Evaluation Improvement of Production Productivity Performance using Statistical Process Control, Overall Equipment Efficiency, and Autonomous Maintenance. Procedia Manufacturing 2 , 186-190.

[8] Argaw Tarekegn Gurmu1 and Ajibade Ayodeji Aibinu2. (2017). Construction Equipment Management Practices for Improving Labor Productivity in Multistory Building Construction Projects. J. Constr. Eng. Manage. , 1-13.

[9] D. B. Phadatare S. B. Charhate. (2016). IMPACT OF CONSTRUCTION EQUIPMENT'S ON BUILDING SITE PRODUCTIVITY. International Journal of Civil Engineering and Technology, 513-520.

[10] Ittiphol Bhurisith1 and Ali Touran, . (2002). Case Study of Obsolescence and Equipment Productivity. JOURNAL OF CONSTRUCTION ENGINEERING AND MANAGEMENT, 357-361.

[11] Jariwala Siddharth1, Jayeshkumar Pitroda2. (2014 (Jariwala Siddharth, Jayeshkumar Pitroda, 2014). International Journal of Advanced Technology in Engineering and Science, 559-567.

[12] Prakash H. Panda\#1, Mr. Sahajanand Kamat\#2. (2017). Productivity Analysis of Pile Driving Equipment in Mumbai. 
International Journal of Civil Engineering , 57-65.

[13] Qing Fan and Hongqin Fan. (2015). Reliability Analysis and Failure Prediction of Construction Equipment with Time Series Models. Journal of Advanced Management Science , 203-210.

[14] Saikumar Tenepalli SS. Asadi K. Sai Kala. (2017). A MODEL STUDY ON COMPARATIVE COST ANALYSIS OF EQUIPMENT MANAGEMENT IN CONSTRUCTION COMPANIES IN TIRUPATI

REGION. International Journal of Civil Engineering and Technology, 72-81.

[15] Venkatesh M.P1 and Saravana Natarajan P.S2. (2019). Improvement of Manpower and Equipment Productivity in Indian Construction Projects. International Journal of Applied Engineering Research , 404-409. 